\title{
GROWTH AND SURVIVAL OF Sclerolobium paniculatum VOGEL AND THE RELATIONSHIP BETWEEN RAINFALL AND THE INCREMENT IN DIAMETER AT DIFFERENT PLANTING SPACINGS ${ }^{1}$
}

\author{
Tainah Silva Narducci ${ }^{2 *}$, Jorge Alberto Gazel Yared ${ }^{3}$ and Silvio Brienza Júnior ${ }^{4}$
}

\footnotetext{
${ }^{1}$ Received on 23.10.2014 accepted for publication on 03.03.2016.

${ }^{2}$ Universidade Federal do Pará, Mestrado em Ciências Ambientais, Belém, PA - Brasil. E-mail:<tainahnarducci@hotmail.com>. ${ }^{3}$ Empresa Brasileira de Pesquisa Agropecuária, Centro de Pesquisa Agroflorestal do Amapá, Macapá, AP - Brasil. E-mail:<jagyared@gmail.com>.

${ }^{4}$ Empresa Brasileira de Pesquisa Agropecuária, Centro de Pesquisa Agroflorestal da Amazônia Oriental, Floresta, Belém, PA - Brasil. E-mail: <silvio.brienza@embrapa.br>.

*Corresponding author.
}

\begin{abstract}
Sclerolobium paniculatum Vogel is a species that has good potential for reclamation of degraded soils. The aim of the investigation was to evaluate the growth and survival of the species and the influence of rainfall on growth in diameter as a function of different spacings (4 m x $2 \mathrm{~m}, 4 \mathrm{~m} \times 3 \mathrm{~m}$, and $4 \mathrm{~m} \times$ $4 \mathrm{~m}$ ). The results indicate that the temporal analysis (period from November 2007 to August 2013) detected significant differences $(\mathrm{p} \leq 0.05)$ in height between the $4 \mathrm{~m} \times 2 \mathrm{~m}$ and $4 \mathrm{~m} \times 4 \mathrm{~m}$ spacings, while no significant difference in diameter was found between the $4 \mathrm{~m} \times 2 \mathrm{~m}$ and $4 \mathrm{~m} \times 3 \mathrm{~m}$ spacings. However, the statistical differences did not persist when the data was analyzed at seven and half years old. Regarding survival, a significant difference was observed only between the $4 \mathrm{~m} \mathrm{x} 4 \mathrm{~m}$ spacing and the others, with superiority to the former. A strong correlation was found between rainfall and the increment in diameter of individuals in the broader spacings $(\mathrm{R}=0.80$ in the $4 \mathrm{~m} \times 3 \mathrm{~m}$ spacing and $\mathrm{R}=0.77$ in the $4 \mathrm{~m} \times 4 \mathrm{~m}$ spacing), while in the denser spacing the correlation was moderate $(\mathrm{R}=0.56$ in the $4 \mathrm{~m} \times 2 \mathrm{~m}$ spacing). Since the spacings adopted did not influence tree growth by the end of the period, the choice will depend on other factors such as survival and costs of implementation and forestry management. Plantations in regions with larger rainfall amplitude may benefit the productivity of the species.
\end{abstract}

Keywords: Forest species; Forestry; Climatic factors.

\section{CRESCIMENTO E SOBREVIVÊNCIA DE Sclerolobium paniculatum VOGEL, E A RELAÇÃO ENTRE A PRECIPITAÇÃO E O INCREMENTO DIAMÉTRICO EM DIFERENTES ESPAÇAMENTOS DE PLANTIO}

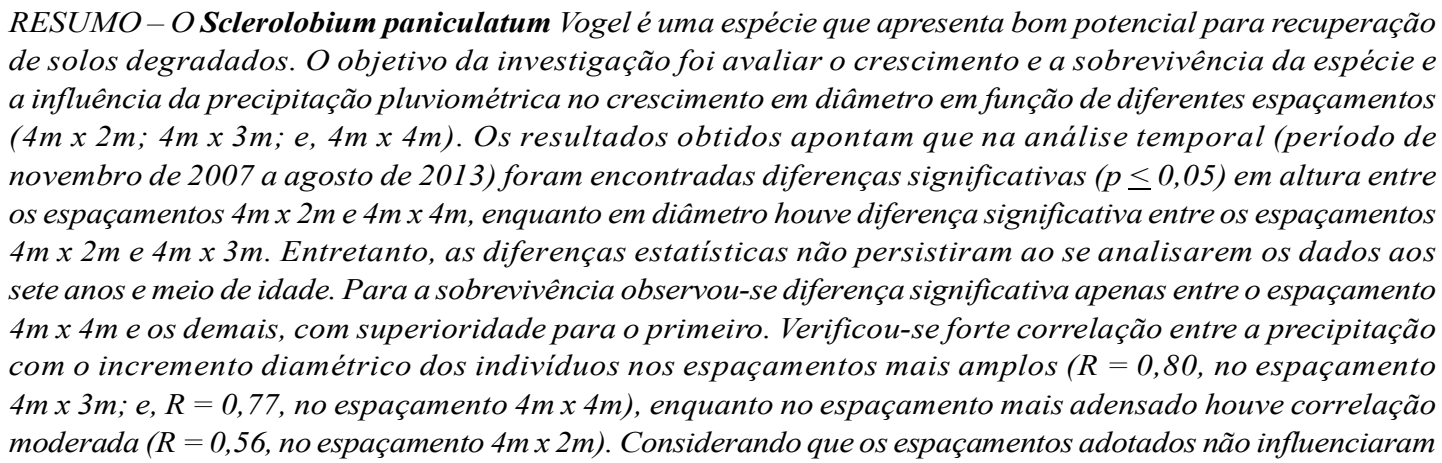


o crescimento das árvores, ao final do periodo, a sua escolha dependerá de outros fatores como a sobrevivência e os custos de implantação e tratos silviculturais dos plantios. Plantios em regiões com amplitude maiores de precipitação poderão beneficiar a produtividade da espécie.

Palavras-chave: Espécies florestais; Silvicultura; Fatores climáticos.

\section{INTRODUCTION}

After an area is disturbed and, if it cannot maintain resilience, i.e., loses the ability to naturally return to a dynamic balance, it is considered degraded. On the other hand, a disturbed ecosystem is capable of resilience (MARTINS, 2013).

Planted forest can be used to restore and maintain Permanent Preservation Areas by protecting springs and streams and preventing river silting, restoring Legal Reserve areas, enabling the rendering of environmental services, and reincorporating areas to the productive process in rural properties, thus providing an additional source of income to the land owner (FERREIRA; GALVÃO, 2000; JANKOWSKY; GALVÃO, 2000; BRIENZA JÚNIOR et al., 2008; MEDRADO et al., 2011).

In order for an area to be recovered, productive techniques that are appropriate to the degraded environment must be chosen. In fact, the techniques chosen are based merely aiming to quickly resolve the local aesthetics or to meet the requirements of environmental legislations with no concern about recovering the ecosystem balance (FERREIRA et al., 2007).

It is important to choose the spacing of forest plantations taking into account not only the final use of the wood, but also the ecological and silvicultural characteristics of the species. It must also be observed that, within the same spacing, different species may not behave the same way (BALLONI; SIMÕES, 1980).

Spacing impacts plant growth rate, felling age, wood quality, forest exploration and management, and production costs. Thus, the choice of spacing influences silvicultural, technological, and economic aspects (BALLONI; SIMÕES, 1980; CASTRO etal., 1998; CHIES, 2005). Therefore, it is important to select appropriate species and the most adequate spacing to recover degraded areas.

Climate is another relevant factor since it influences growth and productivity in plantations. Dendroclimatology presents methods to assess the relation between climate factors and tree growth. The techniques applied in the tree growth analyses in relation to climate are important for natural sciences since they provide knowledge to researchers regarding the impacts of climate changes on forests, as well as on how to improve silvicultural techniques (NUTTO; WATZLAWICK, 2002).

Several species are important to recover degraded areas and several factors must be considered, among which: rusticity, quick growth, and ability to cycle nutrients (SOUZA et al., 2004). Freitas et al. (2012) indicates the species Sclerolobium paniculatum Vogel to recover degraded areas both in conditions where saplings have full sunlight and 50\% shade. Souza et al. (2004) adds that this species has good potential to recover degraded soils, produces high litter deposition, and enables greater diversity to the area through the establishment of other species.

The present study aimed to research the influence of spacing on the growth in height and diameter and on the survival of planted Sclerolobium paniculatum Vogel trees and to assess the influence of precipitation on the periodic current increment (PCI) in the diameter of trees planted in three spacings in order to further silvicultural knowledge so that the most appropriate spacing can be chosen to recover degraded land in legal reserve areas.

\section{MATERIALAND METHODS}

This experiment was carried out in homogeneous Sclerolobium paniculatum Vogel plantations seven and a half years old at Gênesis Farm in the city of Dom Eliseu, PA, Brazil, km 49, BR-222 (latitude 04 33' 10" $\mathrm{S}$ and longitude $47^{\circ} 49^{\prime} 0^{\prime \prime} \mathrm{W}$ ).

The saplings were planted in February 2006. Prior to planting, the pits received $200 \mathrm{~g}$ nitrogen, phosphorus, and potassium (NPK) fertilizer at a 10:28:20 ratio. After planting, top dressings (75 g 10:28:20 NPK) were carried out in the beginning and at the end of the rainy season (SOUSA, 2011).

The local soil was identified as moderate-texture, very clayey dystrophic yellow latosol A(SOUSA, 2011). 
The climate is humid mesothermal and the mean annual temperature is approximately $25^{\circ} \mathrm{C}$. Annual rainfall is regular, ranging from $2,250 \mathrm{~mm}$ to $2,500 \mathrm{~mm}$, however, it is not evenly distributed along the year. Approximately $80 \%$ of rainfall is concentrated between January and June, causing the maximum flood level of rivers. Relative air humidity is around 85\% (PARÁ, 2013).

According to Sousa (2011), the vegetation in the experimental area prior to planting was characterized as a tropical rainforest, which was cleared in October 2005 for use of the wood.

The experimental area is considered disturbed since it had forest coverage before the planting and was deforested. However, it did not lose its resilience capacity and, even if it had not been replanted, could return to its original state.

Data were collected in random sample plots with four repetitions for each of the spacings ( $4 \mathrm{~m} \times 2 \mathrm{~m}$, $4 \mathrm{~m} \times 3 \mathrm{~m}$, and $4 \mathrm{~m} \times 4 \mathrm{~m}$ ). Each spacing was employed in two $50 \mathrm{~m} \times 60 \mathrm{~m}$ plots $\left(3,000 \mathrm{~m}^{2}\right)$ for a total of 18,000 $\mathrm{m}^{2}$ planted with Sclerolobium paniculatum.

Height was measured with a Vertex IV hypsometer while diameter at breast height (DBH) was measured with a diameter tape in November 2007, April and October 2008, May 2009, October 2010 and 2012, and August 2013. The rainfall data were obtained from the National Institute of Meteorology (Instituto Nacional the Meteorologia - INMET).

The softwares Excel 2010, SAS 9.0, and Statistica 8 were used to apply analysis of variance to the variables height and diameter and, when significant, Tukey's test $(5 \%)$ was applied to compare the means.

The analyses of height and DBH for all years of measurement were performed by comparing the samples taking into account the collection dates and the three different spacings.

For analyses of the last year of measurement, August 2013, the samples were compared taking into account the collection date and the three different spacings.

A categorical data model was employed to assess the number of surviving individuals in each spacing. When the goal is to test the hypothesis that all response probabilities are the same for all spacings, the test is known as homogenicity test. This homogenicity hypothesis can be tested by using the chi-squared statistics or the maximum likelihood ratio (PAULINO; SINGER, 2006).

In each period, the mean PCI of each measurement of the diameter of the individuals for each treatment was correlated through Pearson coefficient with the accumulated rainfall. For the latter parameter, the correlation with the period immediately before was investigated.

Pearson correlation coefficient (1982) verifies how much two or more variables are linked by a statistical relation. The values range from +1 to -1 . A strong correlation has values $\geq \pm 0.70$, a moderate correlation has values between \pm 0.30 and 0.70 , and a weak correlation has values $\leq 0.30$.

\section{RESULTS}

\subsection{Growth in Height and Diameter}

Table 1 shows that there is a regression, i.e., the response variables (height and $\mathrm{DBH}$ ) depend on the explanatory variables (date and/or spacing).

Tukey's test showed a significant difference ( $\mathrm{p}$ $<0.0229$ ) in height between the $4 \mathrm{~m} \mathrm{x} 2 \mathrm{~m}$ and $4 \mathrm{~m} \mathrm{x}$ $4 \mathrm{~m}$ spacings. Height did not significantly differ between the $4 \mathrm{~m} \times 2 \mathrm{~m}$ and $4 \mathrm{~m} \times 3 \mathrm{~m}$ spacings $(\mathrm{p}<0.0968)$ or between $4 \mathrm{mx} 3 \mathrm{~m}$ and $4 \mathrm{~m} \mathrm{x} 4 \mathrm{~m}(\mathrm{p}<0.7649)$.

The mean height for all measurement periods (Table 2) was the greatest in the $4 \mathrm{~m} \times 2 \mathrm{~m}$ spacing and the lowest in $4 \mathrm{~m} \mathrm{x} 4 \mathrm{~m}$, however, neither significantly differed at a $5 \%$ level from the $4 \mathrm{~m} \times 3 \mathrm{~m}$ spacing. The opposite occurred for the DBH values, which where the highest for the less dense spacings.

Tukey's test showed a significant difference $(\mathrm{p}<0.0489)$ in diameter between the $4 \mathrm{~m} \mathrm{x} 2 \mathrm{~m}$ and $4 \mathrm{~m} \times 3 \mathrm{~m}$ spacings. Diameter did not significantly differ between the $4 \mathrm{~m} \times 2 \mathrm{~m}$ and $4 \mathrm{~m} \mathrm{x} 4 \mathrm{~m}$ spacings ( $\mathrm{p}<$ $0.0783)$ or between $4 \mathrm{~m} \times 3 \mathrm{~m}$ and $4 \mathrm{mx} 4 \mathrm{~m}(\mathrm{p}<0.9997)$ (Table 2).

The analysis of variance for the final mean height and $\mathrm{DBH}$, at seven and half years old, did not show a significant difference at a $5 \%$ level, i.e., there was no regression and the response variables (height and $\mathrm{DBH})$ are independent from the explanatory variable (spacing) (Table 3 ).

Revista Árvore, Viçosa-MG, v.40, n.3, p.447-454, 2016

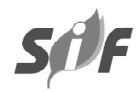


Table 1 - Analysis of variance of the variables height and DBH of Sclerolobium paniculatum for all measurement periods. Tabela 1 - Análise de variância da variável altura e DAP de Sclerolobium paniculatum para todos os períodos de medição.

\begin{tabular}{|c|c|c|c|c|c|c|c|c|c|c|}
\hline \multirow[t]{2}{*}{ Source } & \multicolumn{2}{|c|}{$\mathrm{DF}$} & \multicolumn{2}{|c|}{ Sum of squares } & \multicolumn{2}{|c|}{ Mean squares } & \multicolumn{2}{|c|}{$\mathrm{F}$} & \multicolumn{2}{|c|}{$\mathrm{p}>\mathrm{F}$} \\
\hline & $\mathrm{H}$ & $\mathrm{DBH}$ & $\mathrm{H}$ & $\mathrm{DBH}$ & $\mathrm{H}$ & $\mathrm{DBH}$ & $\mathrm{H}$ & $\overline{\mathrm{DBH}}$ & $\mathrm{H}$ & $\mathrm{DBH}$ \\
\hline Model & 8 & 8 & $54,474.76687$ & $23,120.07418$ & $6,809.34586$ & $2,890.00927$ & $1,725.49$ & 343.87 & 0.0001 & 0.0001 \\
\hline Error & 1,252 & 1,141 & $4,940.80980$ & $9,589.50359$ & 3.94633 & 8.40447 & & & & \\
\hline $\begin{array}{l}\text { Total } \\
\text { correction }\end{array}$ & 1,260 & 1,149 & $59,415.57667$ & $32,709.57777$ & & & & & & \\
\hline Date & 6 & 6 & $54,442.06583$ & $23,058.93457$ & $9,073.67764$ & $3,843.15576$ & $2,299.27$ & 457.28 & 0.0001 & 0.0001 \\
\hline Spacing & 2 & 2 & 32.70104 & 61.13961 & 16.35052 & 30.56980 & 4.14 & 3.64 & 0.0161 & 0.0266 \\
\hline
\end{tabular}

$5 \%$ significance level .

Nível de significância a $5 \%$.

Source: The author.

Fonte: Da autora.

Table 2 - Tukey's test for the variables height and DBH of Sclerolobium paniculatum in different spacings for all measurement periods.

Tabela 2 - Teste de Tukey para as variáveis altura e DAP de Sclerolobium paniculatum em diferentes espaçamentos para todos os períodos de medição.

\begin{tabular}{lcc}
\hline Spacings & Mean H $(\mathrm{m})$ & Mean DBH $(\mathrm{cm})$ \\
\hline $4 \mathrm{~m} \times 2 \mathrm{~m}$ & $10.14 \mathrm{a}$ & $7.949 \mathrm{a}$ \\
$4 \mathrm{~m} \times 3 \mathrm{~m}$ & $9.87 \mathrm{ab}$ & $8.421 \mathrm{~b}$ \\
$4 \mathrm{~m} \times 4 \mathrm{~m}$ & $9.76 \mathrm{~b}$ & $8.416 \mathrm{ab}$ \\
\hline
\end{tabular}

Means followed by the same letter do not differ at $5 \%$ level. As médias seguidas da mesma letra não diferem entre si em nivel de $5 \%$.

Source: The author.

Fonte: Da autora.

\subsection{Tree Survival}

A trend for greater survival in broader spacings was found. Survival was the greatest $(78.3 \%)$ in the least dense spacing, $4 \mathrm{~m} \mathrm{x} 4 \mathrm{~m}$, and the lowest (51.8\%) in the densest spacing, $4 \mathrm{~m} \times 2 \mathrm{~m}$. The $4 \mathrm{~m} \times 3 \mathrm{~m}$ spacing had $62.5 \%$ survival.

Significant differences were found in the response likelihoods among the spacings (Table 4). It can be seen that survival differed between the $4 \mathrm{~m} \times 2 \mathrm{~m}$ and
$4 \mathrm{~m} \times 4 \mathrm{~m}$ spacings and between $4 \mathrm{~m} \times 3 \mathrm{~m}$ and $4 \mathrm{~m}$ $\mathrm{x} 4 \mathrm{~m}$, but not between $4 \mathrm{mx} 2 \mathrm{~m}$ and $4 \mathrm{mx} 3 \mathrm{~m}$, which did not significantly differed.

\subsection{Ratio between Rainfall and Diameter Increase}

Pearson coefficient showed that rainfall and PCI in diameter were strongly correlated with rainfall for the $4 \mathrm{mx} 3 \mathrm{~m}(\mathrm{R}=0.802)$ and the $4 \mathrm{mx} 4 \mathrm{~m}(\mathrm{R}=0.767)$ spacings, while the correlation between rainfall and $\mathrm{PCI}$ in diameter for the $4 \mathrm{~m} \times 2 \mathrm{~m}$ spacing was moderate $(\mathrm{R}=0.562)$.

The $\mathrm{p}$ value in each spacing was not significant at a $5 \%$ level. The relation of rainfall with the $4 \mathrm{~m} \mathrm{x}$ $2 \mathrm{~m}$ spacing obtained $\mathrm{p}=0.245$; with the $4 \mathrm{~m} \times 3 \mathrm{~m}$ spacing, $\mathrm{p}=0.055$; and with the $4 \mathrm{~m} \times 4 \mathrm{~m}$ spacing, $\mathrm{p}=0.075$.

\section{DISCUSSION}

The mean height assessed over the measurement period (Table 2) increased as spacing decreased. Opposite results were found by Sousa (2011) when assessing the growth in height of Schizolobium parahyba var. amazonicum (Huber ex Ducke) Barneby at 40 months

Table 3 - Analysis of variance of the variables height and DBH of Sclerolobium paniculatum for the last measurement period.

Tabela 3 - Análise de variância da variável altura e DAP de Sclerolobium paniculatum para o último período de medição.

\begin{tabular}{|c|c|c|c|c|c|c|c|c|c|}
\hline \multirow[t]{2}{*}{ Source } & \multirow[t]{2}{*}{$\mathrm{DF}$} & \multicolumn{2}{|c|}{ Sum of squares } & \multicolumn{2}{|c|}{ Mean squares } & \multicolumn{2}{|c|}{$\mathrm{F}$} & \multicolumn{2}{|c|}{$p$} \\
\hline & & $\mathrm{H}$ & DBH & $\mathrm{H}$ & DBH & $\mathrm{H}$ & $\mathrm{DBH}$ & $\mathrm{H}$ & $\mathrm{DBH}$ \\
\hline Model & 2 & 18.541949 & 38.025243 & 9.270974 & 19.012621 & 1.16 & 0.86 & 0.3169 & 0.4253 \\
\hline Error & 152 & 1216.855729 & 3361.532177 & 8.005630 & 22.115343 & & & & \\
\hline Total & 154 & 1235.397677 & 3399.557419 & & & & & & \\
\hline
\end{tabular}

$5 \%$ significance level.

Nível de significância a $5 \%$

Source: The author.

Fonte: Da autora.

Revista Árvore, Viçosa-MG, v.40, n.3, p.447-454, 2016 
Table 4 - Analysis of variance and comparison of the variable survival of Sclerolobium paniculatum at seven and a half years old among spacings.

Tabela 4 - Análise de variância e comparação da variável sobrevivência de Sclerolobium paniculatum com sete anos e meio de idade entre os espaçamentos.

\begin{tabular}{lccc}
\hline Source & DF & Chi-squared & p $>$ chi-squared \\
\hline Intercept & 1 & 464.49 & 13.96 \\
Spacing & 2 & 0.0001 & \\
Residue & 0 & & \\
\hline Contrast & & 2.0009 & \\
\hline $4 \mathrm{~m} \times 2 \mathrm{~m} \& 4 \mathrm{~m} \times 3 \mathrm{~m}$ & 1 & 13.93 & 0.1358 \\
$4 \mathrm{~m} \times 2 \mathrm{~m} \& 4 \mathrm{~m} \times 4 \mathrm{~m}$ & 1 & 4.35 & 0.0002 \\
$4 \mathrm{~m} \times 3 \mathrm{~m} \& 4 \mathrm{~m} \times 4 \mathrm{~m}$ & 1 & 0.0369 \\
\hline
\end{tabular}

$5 \%$ significance level.

Nivel de significância a 5\%.

Source: The author.

Fonte: Da autora.

old in the same experimental area as this study. That author obtained greater final mean height in the $4 \mathrm{~m}$ x $3 \mathrm{~m}$ and $4 \mathrm{~m} \times 3.5 \mathrm{~m}$ spacings, which significantly differed compared to the $4 \mathrm{~m} \times 2 \mathrm{~m}$ and $4 \mathrm{~m} \times 4 \mathrm{~m}$ spacings.

Greater growth in diameter (Table 2) was observed in the $4 \mathrm{mx} 3 \mathrm{~m}$ and $4 \mathrm{mx} 4 \mathrm{~m}$ spacings, which match the results by Castro et al. (1998), Sousa (2011), and Leite et al. (1997). Those authors also found that the mean diameter tended to be greater in the broader spacings.

The fact the growth values did not significantly differ among the three spacings corroborate the results found by Castro et al. (1998), who also did not detect a significant effect of the final mean height in planted Sclerolobium paniculatum at seven years old and pointed out that, at this age, the influence of the competition for light and/or nutrients was not reached in the differences spacings. Nevertheless, those authors reported that the greatest height values were found in broader spacings, which is the opposite of the present study. The greater height in less dense plantations in that study might have been because the experiment was carried out in the Cerrado of the state of Amapá, whose characteristics are different from the site of the present study.

The results of height and DBH found in this study are also similar to those reported by Chies (2005) when studying the influence of spacing on the variables height and DBH in the species Pinus taeda L. That author concluded that smaller spacings had lower growth in diameter likely because of greater competition for water, light, and nutrients, which led to greater growth in height.
Souza et al. (2004) recommend $3 \mathrm{~m}$ x $2 \mathrm{~m}$ spacing in the initial plantation of Sclerolobium paniculatum Vogel with the purpose of producing wood in the lowfertility conditions of the Amazon and performing thinning after two years to allow the trees to grow in diameter. However, it is worth pointing out that, if wood production is targeted at energy generation, the trees could be harvested at seven years with no need for thinning even with this spacing.

In an assay carried out by Souza et al. (2010) with 14 species planted under full insolation and ten species planted in secondary forests, Acacia mangium and Sclerolobium paniculatum obtained the best performances in height and mean annual increment (MAI) in height at six years old for both plantation conditions. The DBH of these two species also stood out in the plantation in secondary forest, however, in the assay under full insolation, Sclerolobium paniculatum fell into the group of species with intermediate performance, with DBHs above $10 \mathrm{~cm}$ and MAIs in DBH above $1.8 \mathrm{~cm}$.year ${ }^{-1}$.

Results similar to the ones in the present study were reported by Castro et al. (1998) regarding survival in a study with the same species, Sclerolobium paniculatum Vogel, and at virtually the same age as the present one ( 7 years old). Those authors found that the survival of that species did not significantly differ, with $94 \%$ survival in the largest ( $3 \mathrm{~m} \mathrm{x} 2.5 \mathrm{~m}$ ) and smallest ( $2 \mathrm{~m} \times 1 \mathrm{~m})$ spacings. However, the greatest survival was found for the $2 \mathrm{~m} \times 2 \mathrm{~m}$ spacing at $97 \%$, while the $2.5 \mathrm{~m} \times 2 \mathrm{~m}$ and $1.5 \mathrm{~m} \times 1.5 \mathrm{~m}$ spacings had $93 \%$ survival.

Revista Árvore, Viçosa-MG, v.40, n.3, p.447-454, 2016

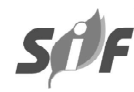


Sclerolobium paniculatum was one of the species with the highest survival rates in the study by Yared et al. (1988), who found that in a plantation with 15 species in Belterra, PA, Brazil, the species with the best survival at five and a half years old were Laetia procera (Poepp.) Eichler at 96.7\%, Sclerolobium paniculatum Vogel at $94.7 \%$, and Enterolobium schomburgkii (Benth.) Benth at 93.2\%.

Sousa (2011) found results similar to those in this study when analyzing the survival of Schizolobium parahyba var. amazonicum (Huber ex Ducke) Barneby at 40 months old in different spacings. That author verified that the plants in the denser spacings, $4 \mathrm{~m}$ x $2 \mathrm{~m}$ and $4 \mathrm{~m} \times 2.5 \mathrm{~m}$, had the lowest survival rate at $82.2 \%$ and $73.8 \%$, while the $4 \mathrm{~m} \times 4 \mathrm{~m}$ spacing, less dense, had the highest survival rate at $91.4 \%$. The author justifies that, when individuals are planted closer to one another, they compete for more space, water, and nutrients, which may cause greater tree mortality.

Brienza Júnior et al. (2011) observed that survival of Sclerolobium paniculatum was $83.8 \%$ at 12 months old in a plantation with $2 \mathrm{mx} 1 \mathrm{~m}$ spacing. This result is above the ones in the present study in broader spacings, however, when these results are compared, it must be taken into account that the plantation in Brienza Júnior et al. (2011) was only one year old, while in this study the plantation was seven and a half years old.

In the assay by Souza et al. (2010), Sclerolobium paniculatum was not one of the species with the highest survival rates, at $63.9 \%$ in the plantation under full sunlight and $27.8 \%$ in the plantation in secondary forest at approximately 25 years old. The result of survival in the plantation under full sunlight is around the same as in the plantation in the $4 \mathrm{~m} \mathrm{x} 3 \mathrm{~m}$ spacing in the present study. Freitas et al. (2012) suggests this species be planted under full insolation or with $50 \%$ shade. It can be seen that, in the plantation in the old secondary forest, survival was very low and that the denser spacing ( $4 \mathrm{~m} \times 2 \mathrm{~m}$ ), which provides more shade between trees, had the lowest survival.

The increment in diameter of trees in the $4 \mathrm{~m} \mathrm{x}$ $3 \mathrm{~m}$ and $4 \mathrm{mx} 4 \mathrm{~m}$ spacings were more influenced by rainfall than those in the $4 \mathrm{~m} \times 2 \mathrm{~m}$ spacing. The growth in diameter of the individuals may also have been influenced by other meteorological factors (BOTOSO;
VETTER, 1991) not considered in this research such as relative humidity, maximum and minimum temperatures, and solar radiation.

The different plantation densities also impacted tree growth. The broader spacings were strongly correlated with rainfall, similarly to what was reported in a study on population density of Eucalyptus grandis in which Leite et al. (1997) observed that, in the period with more water availability in the soil, the trees in the less dense plantations grew more compared with the denser plantations. That may be because of less competition for water among the individuals (PAULESKI, 2010).

Results similar to those in the present study were found in a similar study by Montagner and Yared (1983), where the increment in DBH of Cordia goeldiana Huber had a highly significant positive correlation with rainfall $(\mathrm{R}=0.70)$.

Dias (2009) assessed the mean monthly increment (MMI) in diameter of trees as a function of rainfall in a dryland primary forest in the central Amazon and found that the variation in increment is related to the rainfall rate and that the higher MMI values occurred in the months with high rainfall rates, while the lowest increments occurred in the less rainy months. The same relations were observed by Botoso and Vetter (1991) in a study on the growth rate of eight tree species in the Amazon. The results showed low or sometimes no increment in circumference in the periods with low rainfall.

The relation between rainfall and mean increment in diameter of other forest species had opposite results to this study, with low values between $\mathrm{R}=-0.21$ with 0.485 significance for the regional species Blepharocalyx salicifolius Kunth and $\mathrm{R}=0.257$ with 0.396 significance for the invasive exotic Hovenia dulcis Thunb. in a mixed ombrophilous alluvial forest in the Brazilian state of Paraná (KANIESKI et al., 2012).

Machado et al. (2014) also found a weak correlation between rainfall and increment in diameter of Araucaria angustifolia (Bert.) $\mathrm{O}$. Kuntze at $\mathrm{R}=0.15$ and a moderate correlation with the increment of Pinus taeda L. at $\mathrm{R}=0.32$, with both species in the initial phase. With this result, those authors reveal that the increment in diameter of $A$. angustifolia is little sensitive to climate variations and is more impacted by energy stores and 
metabolic activities, factors related to a step in the adaptation of the species to the area.

\section{CONCLUSION}

According to the results found, it can be concluded that:

For the variable height, no differences were observed among the plantation densities and any of the spacings can be used. Thus, the choice of spacing will depend on other factors such as purpose and financial conditions available;

The less dense spacings showed greater growth in diameter, which make them possible options for plantation since they require fewer saplings and are more financially viable;

The survival rate increased as spacing increased, with the highest survival rate found in the less dense spacing, which may have been due to less competition among the trees for natural resources;

The correlation between rainfall and increment in diameter was moderate to strong, which shows the sensitivity of this species's growth to water availability.

\section{REFERENCES}

BALLONI, E. A.; SIMÕES, J. W. O espaçamento de plantio e suas implicações silviculturais.

Série Técnica IPEF, v. 1, n. 3, p.1-16, 1980.

BOTOSO, P. C.; VETTER, R. E. Alguns aspectos sobre a periodicidade e taxa de crescimento em 8 espécies arbóreas tropicais de floresta de terra firme (Amazônia). Revista do Instituto Florestal, v. 3, n. 2, p. 163-180, 1991.

BRIENZA JÚNIOR, S.; PEREIRA, J. F.; YARED, J. A. G.; MOURÃO JÚNIOR, M; GONÇALVES, D. A. de.; GALEÃO, R. R. Recuperação de áreas degradadas com base em Sistema de produção florestal energético-madeireiro: indicadores de custos, produtividade e renda. Amazônia: Ciência e Desenvolvimento, v. 4, n. 7, p. 197-219, 2008.

BRIENZA JÚNIOR, S.; OLIVEIRA, R. P. de.; DENICH, M.; VLEK, P. L. G. Plantio de árvores de crescimento rápido para recuperação de áreas agrícolas na Amazônia Oriental brasileira: estudo de caso com produção de milho e mandioca.
Pesquisa Florestal Brasileira, v. 31 , n. 68, p. 347-353, 2011.

CASTRO, A. W. V. de; FARIAS NETO, J. T. de; CAVALCANTE, E. da S. Efeito do espaçamento na produtividade de biomassa de taxi-branco (Sclerolobium paniculatum Vogel). Acta Amazônia, v.28, n.2, p.141-146, 1998.

CHIES, D. Influência do espaçamento sobre a qualidade e o rendimento da madeira serrada de Pinus taeda L. $123 \mathrm{f}$. Dissertação (Mestrado em Engenharia Florestal) Setor de Ciências Agrárias, Universidade Federal do Paraná, Curitiba, 2005.

DIAS, D. P. Fotossíntese e crescimento em diâmetro de árvores em função da temperatura e da precipitação numa floresta primária de terra-firme na Amazônia Central. 123 f. Tese (Doutorado em Ciências de Florestas Tropicais) INPA/UFAM, Manaus, 2009

FERREIRA, C. A.; GALVÃO, A. P. M. Importância da Atividade Florestal no Brasil. In: GALVÃO, A. P. M. (Org.). Reflorestamento de Propriedades Rurais para fins Produtivos e Ambientais: um guia para ações municipais e regionais. Brasília, DF: Embrapa, 2000. p.15-18.

FERREIRA, W. C.; BOTELHO, S. A; DAVIDE, A. C.; FARIA J. M. R. Avaliação do crescimento do estrato arbóreo de área degradada revegetada à margem do rio Grande, na usina hidrelétrica de Camargos, MG. Revista Árvore, v.31, n.1, p.117-185, 2007.

FREITAS, G. A.; VAZ-DE-MELO, A.; PEREIRA, M. A. B.; ANDRADE, C. A. O.; LUCENA, G. N.; SILVA, R. R. Influência do sombreamento na qualidade de mudas de Sclerolobium paniculatum Vogel para recuperação de área degradada. Journal of Biotechnology and Biodiversity, v. 3, n. 3, p. 5-12, 2012.

JANKOWSKY, I. P.; GALVÃO, A. P. M. Principais usos da madeira em reflorestamento. In: GALVÃO, A. P. M. (Org.). Reflorestamento de Propriedades Rurais para fins Produtivos e Ambientais: um guia para ações municipais e regionais. Brasília, DF: Embrapa, 2000. p.57-70.

Revista Árvore, Viçosa-MG, v.40, n.3, p.447-454, 2016 
KANIESKI, M. R.; SANTOS, T. L.; GRAF NETO, J.; SOUZA, T.; GALVÃO, F.; RODERJAN, C. V. Influência da Precipitação e da Temperatura no Incremento Diamétrico de Espécies Florestais Aluviais em Araucária - PR. Floresta e Ambiente, v. 19, n. 1, p. 17-25, 2012.

LEITE, F. P.; BARROS, N. F.; NOVAIS, R. R.; SANS, L. M. A.; FABRES, A. S. Crescimento de Eucalyptus grandis em diferentes densidades populacionais. Revista Árvore, v.21, n.3, p.313-321, 1997.

MACHADO, S. A.; ZAMIN, N. T.; NASCIMENTO, R. G. M.; SANTOS, A. A. P. Efeito de Variáveis Climáticas no Crescimento Mensal de Pinus taeda e Araucaria angustifolia em Fase Juvenil.

Floresta e Ambiente, v. 21, n. 2, p. 170-181, 2014.

MARTINS, S. V. Recuperação de áreas degradadas: ações em áreas de preservação permanente, voçorocas, taludes rodoviários e de mineração. Viçosa: Aprenda Fácil Editora, 2013. 270p.

MEDRADO, M. J. S.; SILVA, V. P.; MEDRADO, R. D.; DERETI, R. M. Potencial florestal na conservação dos recursos naturais. Documentos 212. Colombo: Embrapa - Empresa Brasileira de Pesquisa Agropecuária. 2011. 53p.

MONTAGNER, L. H.; YARED, J. A. G. Aspectos da fenologia de Cordia goeldiana Huber e suas relações com alguns parâmetros climáticos. Belém: EMBRAPA-CPATU, 1983. 18p. (EMBRAPA-CPATU. Boletim de Pesquisa, 54).

NUTTO, L.; WATZLAWICK, L. F. Relações entre Fatores Climáticos e Incremento em Diâmetro de Zanthoxylum rhoifolia Lam. E Zanthoxylum hyemale St. Hil. Na Região de Santa Maria, RS. Boletim de Pesquisa Florestal, n. 45, p. 41-55, 2002.
PARÁ, Secretaria de Estado de Planejamento, Orçamento e Finanças. Estatística municipal Belém: Dom Eliseu. Pará, 2013. 53p.

PAULESKI, D. T. Influência do espaçamento sobre o crescimento e a qualidade da madeira de Pinus taeda L. 196f. Tese (Doutorado em Engenharia Florestal) Universidade Federal de Santa Maria, Santa Maria. 2010.

PAULINO, C. D.; SINGER, J. M. Análise de dados categorizados. São Paulo: Edgard Blücher, 2006. 648 p.

PEARSON, K. The grammar of Science. London, J. M. Dentand Company. 1982.

SOUSA, V. G. de. Comportamento silvicultural e dinâmica de serapilheira em plantios de duas espécies florestais na Amazônia oriental brasileira. $111 \mathrm{f}$. Dissertação (Mestrado em Ciências Ambientais) Instituto de Geociências, Universidade Federal do Pará, Museu Paraense Emilio Goeldi e Embrapa, Belém, 2011.

SOUZA, C. R.; LIMA, R. M. B.; AZEVEDO, C. P.; ROSSI, L. M. B. Taxi-branco (Sclerolobium paniculatum Vogel). Manaus: Embrapa Amazônia Ocidental, 2004. 23p. (Embrapa Amazônia Ocidental. Documentos; 34).

SOUZA, C. R.; AZEVEDO, C. P.; LIMA, R. M.; ROSSI, L. M. B. Comportamento de Espécies florestais em plantios a pleno sol e em faixas de enriquecimento de capoeira na Amazônia. Acta Amazônica, v. 40, n. 1, p. 127-134, 2010.

YARED, J. A. G.; KANASHIRO, M.; CONCEIÇÃO, J. G. L. Espécies florestais nativas e exóticas: comportamento silvicultural no Planalto do Tapajós. Belém: EMBRAPA-CPATU, 1988. 29p. (Documentos, 49). 